\title{
PRICING TO MARKET BEHAVIOUR AND THE IMPACTS ON EXPORT PRICES OF INDONESIAN INDUSTRIAL PRODUCTS
}

\author{
Pratiwi D. Chondro \\ Postgraduate Program in Economics, \\ Faculty of Economics and Business,University of Indonesia \\ Depok, Indonesia \\ tyas.chondro@gmail.com
}

\author{
Telisa A. Falianty \\ Postgraduate Program in Economics, \\ Faculty of Economics and Business,University of Indonesia \\ Depok, Indonesia
}

\begin{abstract}
In this paper, the pricing behavior of Indonesian Industrial Product Exporters was studied by estimating the degree of Exchange Rate Pass Through (ERPT) of Industrial Export Product Price (at the 4-digit level of Harmonized System classification) towards two Indonesian major trading partners in facing the exchange rate fluctuations during 2005-2014 on basis of the market heterogeneity. The Pricing to Market (PTM) model was estimated through the panel data regression model of exports to China and Japan markets. This was to distinguish commodities based on its industrial sector (2 digit ISIC classification) and to correct changes in the level of inflation and openness in the export destination market, a macroeconomic policy index partly reflecting changes in exporter's costs, the share of the exporter in the destination market and the share of the products in the exporter's total exports. It was found that, in Indonesia, differences between export markets are more important than differences across industry. To sum, when the PTM behavior occurs, a country using exchange rate as an instrument to fix the trade balance would face challenges.
\end{abstract}

Keywords: Pricing to Market, Market Heterogeneity, Product Differentiation, Indonesia

\section{INTRODUCTION}

In the international trade, exchange rates have an important relationship with the price level because they represent the interrelationships between domestic and foreign prices. The Law of One Price (LOP) theory states that a product will be sold at the same price in all locations after considering exchange rates between the exporter and importer countries. On the contrary, Kenneth Rogoff (1996) suggested that studies with diverse sources of data and empirical methods have tested and rejected the LOP, including research conducted by Kravis \& Lipsey (1977), Isard (1977), Richardson (1978), and Giovannini (1988). According to Engel (1993) and Engel \& Rogers (1994), the deviation from LOP theory mostly happen because most of the price of goods is determined in the currency of the importer country and often is not adjustable. As a matter of facts, the real exchange rate movements are mainly due to nominal exchange rates fluctuations. This results in exchange rate movements having a very small effect on import prices.
Changes in export prices in the currency of the importer country (import price) which is a response to exchange rate changes between exporter and importer countries are referred as Exchange Rate Pass-Through (ERPT). ERPT is said to be perfect (full ERPT) when the response to changes in export prices in the currency of the importer country to exchange rate changes is 1: 1 . This can happen when the mark-up value of the price from the cost and marginal cost is constant (Goldberg \& Knetter, 1997). The ERPT will be imperfect (Incomplete ERPT) when 1\%-change in the exchange rate causes the export price to change less than $1 \%$. Currently, various studies on ERPT have reached a consensus that there is no full ERPT (exchange rate absorption is not perfect). This applies both to developed and developing countries (Campa \& Goldberg, 2005).

Various studies analyzing the relationship between exchange rate response and import/export prices reach different conclusions, but mostly suggest that there is a tendency for ERPT decline (Mishkin, 2008). Among the various empirical studies that support the assertion that there is a decrease in the degree of ERPT, the majority took samples from developed countries, for example, Marazzi et.al, (2005) who took the sample in USA found that the ERPT coefficient on import prices fell from 0.5 in the 1980 s to 0.2 in the last decade. Similarly, Otani et.al, (2003) indicated a decline in ERPT on import prices in Japan since the 1990s.

However, studies have suggested otherwise, for example the results of a McCarthy's (2007) study conducted in the industrialized countries found that exchange rate changes have a high ERPT effect on import prices. While for the various studies on ERPT in developing countries, the majority stated that ERPT degrees were significant and did not decrease (Ito et al., 2005; Khundrakpam, 2007).

When the degree of ERPT to the price is perfect, then the depreciation of a country's currency is expected to be an opportunity to improve the export performance of a country and on the other hand can decrease the dependence on imported goods so that it has implications on the improving condition of the trade balance. The PTM behavior causing exchange rate changes has no significant impact on the condition of the trade balance (Ito et al., 2005). This is indicated by the results of the Knetter study (1989) which stated that the practice of PTM by importers by limiting the rise in import prices in US currency causes import prices in the US does not rise proportionately with changes in exchange 
rates that occur and implicate the continued deficit in the trade balance in US even after US\$ suffered a sharp depreciation. A study by Shimizu \& Sato (2015) also showed that the yen depreciation policy imposed by the Japanese Government is not able to improve the trade balance deficit experienced by Japan because when Yen depreciates, Japanese exporting companies do not lower their export prices in the currency of importer countries and absorbing the exchange rate changes by increasing its mark-up rate to increase profits.

\section{LITERATURE REVIEW}

The PTM phenomenon is made possible because of the existence of imperfect competition and associated with mark up prices. When the exchange rate changes, the exporter will change the price in its domestic currency to stabilize its export price in the currency of the importer country, which implies ERPT imperfections on import prices. This export price behavior framework is the starting point to analyze PTM's behavior on export prices. One of the theoretical researches to analyze the behavior of PTM is a model developed by Knetter (1989) and Gagnon \& Knetter (1995). A company that produces goods for export in a number of different countries (i) is being modeled. The profit function of the exporting company is the difference between the sales revenue and the production cost from goods $\mathrm{j}$ to country $\mathrm{i}$ :

$$
\pi=\sum_{i=1}^{n} p_{i} q_{i}\left(\frac{p_{i}}{e}\right)-C\left(\sum_{i=1}^{n} q_{i}\left(\frac{p_{i}}{e}\right), w\right)(1)
$$

where $\mathrm{p}$ is the export price in the currency of the exporter, $\mathrm{q}$ is the sum of the export demand which is the function of the export price in the eyes of the buyer country, e is the exchange rate (the price of destination country currency in terms of the exporter currency), $\mathrm{w}$ is the input price index, and $\mathrm{C}(\Sigma \mathrm{q}, \mathrm{w})$ is the company's cost function.

The condition of the first order derivative that reflect the function of profit maximization of the company is:

$$
p_{i}=M C\left[\frac{\eta_{i}\left(\frac{p_{i}}{e}\right)}{\eta_{i j}\left(\frac{p_{i}}{e}\right)-1}\right], \mathrm{i}=1, \ldots, \mathrm{n}
$$

where $\eta$ is the absolute value of the price elasticity of demand in the foreign market. Using log-linear approximation via total differentiation, and collecting terms for dlnpi on the left-hand Equation (2) can be written as :

$$
d \ln p_{i}=\tau_{i}+\left(1-\delta_{i}\right) d \ln M C_{i}+\delta_{i} d \ln e
$$

where

$$
\delta_{i}=\frac{d \ln \eta_{i}}{\operatorname{dln}\left(\frac{p_{i}}{e}\right)}\left[1-\eta_{i}+\frac{d \ln \eta_{i}}{\operatorname{dln}\left(\frac{p_{i}}{e}\right)}\right]^{-1}
$$

is a function of both the level and the elasticity of $\eta_{i}$, and $\tau_{i}$ is a constant terms that representing sector-specific intercept. The coefficient $\delta_{i}$ is a coefficient of pricing-to-market, which can be analyzed as a coefficient of pass-through by assuming that exchange rates have no effect on the exporter's cost of production. If $\delta=0$, there is perfect pass-through to export price in domestic currency (no PTM). If $\delta=1$, there is no pass-through to export price in foreign currency prices (full PTM) because the export price in terms of domestic currency is only determined by external factors.

The Exchange Rate Pass-Through will be incomplete if the markups vary with exchange rate because the ERPT to foreign currency coefficient is the coefficient of pass-through to domestic currency minus one. The pass-through to export prices is an important tools to measure the pricing behavior of exporters in different products. The degree of exchange rate pass-through depends on the markups and product differentiation's level that will affect the imperfect competition's degree.

The existing empirical studies by, among others, Mann (1986), Knetter (1989, 1993) and Marston (1990), focus on many advanced industrial countries such as US, Japan, Germany, and the UK. The results of the studies document interesting facts about PTM, such as: the mark-up adjustment of prices on production costs made by Japanese and German exporters in order to keep the price of goods in the currency of the importer countries remain stable on a wide range of industries. This adjustment does not happen to the exporters of US industry. The studies also found that the behavior of PTM occured varies between countries. According to Knetter (1993), different PTM behaviors were found between different industries and found no evidence of different PTM across countries in the same industry.

ERPT research on emerging markets is mostly done at the aggregate level, including country-to-country comparison such as Barhoumi (2006), Choudhri et al. (2005), and Choudhri \& Hakura (2006). Important result of the research is that ERPT imperfections can also occur in the emerging market, but generally ERPT degree in emerging market is still bigger than in the developed countries.

Mumtaz et al. (2006) showed that ignoring sectorial heterogeneity can produce biased estimates, particularly in the context of dynamic regression estimates. This is in line with the results of the Goldberg \& Knetter (1997) study which stated that different degrees of PTM are more visible among industries than between countries in the same industry. This encourages research on ERPT based on estimates at the product level. However, most studies of both ERPT and PTM using extended sectorial dimensions with time series analysis have limitations in both the timeframe and the low disaggregation level making it extremely difficult to generalize the results of these studies.

This study tries to fill the void in the existing literature through the analysis of the degree of PTM to the Indonesian export prices are more up to date by using data of 4-digit HS industrial products with a longer period than the previous research, from 2005 to 2014 . In the period, global financial crisis occurred and adequately affect the economic conditions in the world. Therefore, it is expected that this study could show different pricing behavior by Indonesian exporters and would give the value of degrees ERPT / PTM which is different from the previous studies. In addition, the study also wants to see whether or not the market heterogeneity and industrial sectors differences affect the difference in Indonesian export prices.

The hypothesis in this research is, There are practices of PTM in the export activities in Indonesia. Differences in the price of Indonesian industrial products exports between destination countries are caused by market heterogeneity and industry differences. The results of the study found that the degree of PTM in Indonesia significantly is differed by market destination, and not by industry difference.

\section{METHODS}

The export price in Rupiah is proxy-ed by using the export value unit and will be regressed with the bilateral exchange rate between Indonesia and each of its trading partner countries in order to determine the amount of ERPT 
degrees on the export price. Another variable suspected of having a relationship with PTM behavior is the share of products exported to market destinations, as the Feenstra et al. (1996) study results in which exporters with enormous share of market destinations will have a high degree of ERPT. In addition, according to the results of the study, increased levels of openness to trade from export destination countries to lowcost countries forced price competition and lowered the degree of other exporters' ERPT to that market.

Another thing to consider is a macroeconomic device like the inflation rate. In general, emerging countries are more vulnerable to inflation compared to developed countries (Montiel, 2003). The importance to control inflation variable caused by its relation to mark up and marginal cost changes. (Banerjee \& Russell, 2001).

As many studies of ERPT / PTM, the study will use a reduced form of the model theoretical equation (5), as well as taking into account the various control variables mentioned earlier (openness, share product, inflation and the index Policy), so the specification of empirical for Indonesian exports to $\mathrm{j}$ trade partner countries during the period $\mathrm{t}$ are:

$$
\begin{gathered}
d \ln P_{j t}=\alpha_{j}+\delta_{j} \text { dlne }_{j t}+\lambda_{j} \text { Infl }_{j t}+\phi_{j} \text { Open }_{j t}+\mu_{j} \text { INAShare }_{j t}+ \\
\gamma_{j} \text { BudgetSurplus }_{t}+\theta_{j} \text { InflIna }_{t}+\omega_{j} \text { OpenIna }_{t}+\varepsilon_{j t}
\end{gathered}
$$

where $\alpha_{j}=\tau_{j}+\left(1-\delta_{j}\right) d \ln M C_{j}$ is a constant form which is a sector-specific intersep; $d \ln \mathrm{P}_{\mathrm{it}}$ is a change of export price $\operatorname{logs}$ in domestic currency (in this case rupiah); dlne it $_{\text {it }}$ a variation of $\log$ bilateral exchange rates (currency of export destination countries per unit of currency of the exporting countries); InflFr it $_{\text {is }}$ the rate of inflation in the export destination country; OpenFr $r_{i t}$ is the level of trade openness in the destination country; INAshare it $_{\text {in }}$ the market share of export products in each trading partner country; BudgetSurplus, InflIna, and OpenIna are representing Indonesian macroeconomic policy (which is inflation, trade openness, and surplus budget).

Equation (6) will be regressed on basis of export destination countries (China and Japan) to see the difference in pricing behavior among export destination countries and will also be re-sorted according to the industrial sector differences for each of the trading partner countries. The data used in this study come from various sources, among others:

Table 1. Data Sources Used in Research

\begin{tabular}{|l|l|c|}
\hline \multicolumn{1}{|c|}{ Data } & \multicolumn{1}{|c|}{ Source } & Period \\
\hline $\begin{array}{l}\text { Variations of natural logarithm } \\
\text { of export prices of Indonesian } \\
\text { industrial exports (proxyed by } \\
\text { value export units) }\end{array}$ & $\begin{array}{l}\text { UN- } \\
\text { Comtrade }\end{array}$ & $2004-2014$ \\
\hline $\begin{array}{l}\text { Variations of the natural } \\
\text { logarithm of annual bilateral } \\
\text { exchange rate Indonesia with } \\
\text { their respective trading partners }\end{array}$ & IFS IMF & $2004-2014$ \\
\hline $\begin{array}{l}\text { Inflation rate of trading partner } \\
\text { countries }\end{array}$ & Worldbank & $2005-2014$ \\
\hline $\begin{array}{l}\text { Trade openness trading } \\
\text { partners }\end{array}$ & $\begin{array}{l}\text { WITS- } \\
\text { Worldbank }\end{array}$ & $2005-2014$ \\
\hline INAShare & $\begin{array}{l}\text { UN- } \\
\text { Comtrade }\end{array}$ & $2005-2014$ \\
\hline Budget Surplus & OECD & $2005-2014$ \\
\hline InflIna & Worldbank & $2005-2014$ \\
\hline OpenIna & Worldbank & $2005-2014$ \\
\hline
\end{tabular}

\section{RESULT AND DISCUSSION}

This study attempts to analyze the pricing behavior of Indonesian exporters based on different market destination countries (in this case Japan and China) and based on industry differences in 2005-2014 period. Although there has been earlier research on the degree of ERPT in Indonesia based on export destination countries for some sectors, but as far as the researcher's knowledge, this study is the first study to analyze differences in pricing behavior by considering the industry differences with the use of more up to date data.

Various empirical studies have shown that the export pricing strategy is strongly influenced by inflationary conditions in export destination countries (e.g. Taylor, 2000, Montiel, 2003; and Banerjee \& Russell, 2001). On the other hand, the relationship between export prices and export share in trading partner countries could, in theory, is positive or negative. Feenstra (1989) showed that ERPT will be high in exporters who have a large market share in the destination market. When market share is high, the company will face a smaller competition so its ERPT will be perfect. With a small or medium market share, theoretical relationships are not linear and sensitive to the assumptions of how consumers demand patterns and corporate interactions (Yang, 1998).

Another variable tried to control in this study is the level of trade openness in trading partner countries. Bergin \& Feenstra (2009) stated that the higher level of trade openness in a country forces price competition so that exporters who sell their products in the market must lower the price of their products in order to remain competitive in those markets.

Differences in the degree of PTM, according to Knetter (1993) are more visible among different industries than between different countries in the same industry. The more differentiated a product can lead to imperfect competition that can increase the potential presence of mark ups. Industrial sectors are classified into top 10 Indonesian industrial products at 2 digit ISIC classification level.

The panel data regression model was performed to estimate the behavior of exporters of Indonesian industrial products based on the Export Destination Countries (Table 2), and based on industry difference (Table 3). To see the difference in the degree of PTM among the two main trading partner countries, a regression of each partner country is conducted, with the following estimates:

Table 2. Estimation Results of Pricing Behavior Based on Export Destination

\begin{tabular}{|c|c|c|}
\hline & China & Japan \\
\hline dlnE & $0.625 * *$ & $0.570 * *$ \\
\hline Open & $-0.023 * * *$ & 0.007 \\
\hline Infl & $0.054 * * *$ & $0.049 *$ \\
\hline InaShare & $-1.461 * * *$ & $-0.890 * * *$ \\
\hline Budget Surplus & $-0.191 * * *$ & $-0.143 * * *$ \\
\hline OpenIna & $-0.019 * *$ & $-0.017 * * *$ \\
\hline InflIna & $0.042 * * *$ & -0.011 \\
\hline const & $10.849 * * *$ & $10.309 * * *$ \\
\hline
\end{tabular}

Description: *** significant at the level of $1 \%$;** significant at the level of $5 \%$; * significant at the level of $10 \%$

Based on Table 2, it is generally found that the degree of absorption of imperfect exchange rate changes (statistically, the coefficient is between 0 and 1) reflects the behavior of PTM on exporters of industrial products of Indonesia. Estimation results show that the average degree of PTM is by 
$60 \%$ or ERPT is $36 \%$. It shows that the majority of Indonesian export product prices are determined in the currency of the trading partner countries. Therefore, when the Rupiah depreciates against the trading partner country's currency, Indonesian exporters will keep the export price in the trading partner currency stable by absorbing the exchange rate changes. This also indicates that the occurrence of imperfection ERPT and proves the existence of price discrimination. Moreover, the relatively low degree of ERPT implies a high degree of price competition in the trading partner countries. This is similar to the results of Banik \& Biswas (2007) study which states that the low degree of price competition corresponds to a high degree of ERPT.

Based on the estimation results (Table 2), there is a positive relationship between the inflation rate in trading partner countries and the export price in Rupiah which affirms the importance of the trading partner country's macroeconomic conditions. This is in line with the results of the study of Gaulier et al. (2008), Campa \& Goldberg (2005), and Taylor (2000) which stated that there is a positive relationship between the rate of inflation in the country destination with export price. In addition, according to Campa \& Goldberg (2005), the degree of ERPT on import prices will fall on stable economic conditions with low inflation rate.

The level of trade openness in China is negatively related to changes in export prices. This means that the more open markets in trading partner countries, the more they will force Indonesian exporters to lower their export prices in the destination market. According to Bergin \& Feenstra (2009), it is because with the increasing trade openness, it will increase the trade competition so that to stay competitive in that market, the exporter must lower the price of the product. However, the estimation result shows that there is no evidence that the level of trade openness in Japan affecting export price. It is probably due to Japan's low level of trade openness during the observations.

Internally, Indonesia is characterized by a macroeconomic policy such as budget surplus, inflation and level of openness to trade in Indonesia, and externally with its share in each trading partner country. In general, it is showed in Table 3 that there is a negative correlation between the index of Indonesian macroeconomic policy with export prices, which means that macroeconomic policy conditions in the study period is so good enough that they can lead to the decline in export prices in order to increase the competitiveness of exporters in the international market. Feenstra (1989) showed that ERPT will be high in exporters who have a large market share in the destination market. When the market share is high, the company will face a smaller competition so that its ERPT will be perfect. With a small or medium market share, theoretical relationships are not linear and sensitive to the assumptions of how consumers demand patterns and corporate interactions (Yang, 1998). From the research results, where the market share of Indonesia in the both trading partner countries is quite small, there is a positive relationship between the export share and the export price.

Besides estimating the degree of PTM based on export destination, this study also estimated the PTM degree based on industrial sector. The results of PTM estimation based on industrial sectors level are:
Table 3. Estimation Results of Pricing Behavior Based on Industrial Sector

\begin{tabular}{|c|c|c|}
\hline & China & Japan \\
\hline $\begin{array}{l}\text { Manufacture of Food Products } \\
\text { (ISIC 10) }\end{array}$ & $0.718^{*}$ & $0.533^{*}$ \\
\hline $\begin{array}{l}\text { Manufacture of chemicals and } \\
\text { chemical products (ISIC 20) }\end{array}$ & 0.617 & 0.626 \\
\hline $\begin{array}{l}\text { Manufacture of paper and } \\
\text { paper products } \\
\text { (ISIC 17) }\end{array}$ & 1.544 & -0.126 \\
\hline $\begin{array}{l}\text { Manufacture of coke and } \\
\text { refined petroleum products } \\
\text { (ISIC 19) }\end{array}$ & -1.840 & 0.610 \\
\hline $\begin{array}{l}\text { Manufacture of other non- } \\
\text { metallic mineral products } \\
\text { (ISIC 23) }\end{array}$ & 1.079 & 0.107 \\
\hline $\begin{array}{l}\text { Manufacture of rubber and } \\
\text { plastics products (ISIC 22) }\end{array}$ & -0.311 & 0.384 \\
\hline $\begin{array}{l}\text { Manufacture of basic metals } \\
\text { (ISIC 24) }\end{array}$ & 0.709 & $0.494 * * *$ \\
\hline $\begin{array}{l}\text { Manufacture of textiles (ISIC } \\
13 \text { ) }\end{array}$ & 0.106 & $1.099 * *$ \\
\hline $\begin{array}{c}\text { Manufacture of furniture } \\
\text { (ISIC 31) }\end{array}$ & $-1.102 * *$ & -1.115 \\
\hline $\begin{array}{l}\text { Manufacture of fabricated } \\
\text { metal products, except } \\
\text { machinery and equipment } \\
\text { (ISIC 25) }\end{array}$ & -0.027 & 0.914 \\
\hline
\end{tabular}

Although the degree of PTM to the export price of Indonesian industrial products shows a fairly high value, around $60 \%$, based on the estimation results, but when examined by sector, it turns out that not all industrial sectors apply the behavior of PTM to export prices. Based on the industry differences (Table 6), it can be seen that from 10 industrial sector commodity, the PTM behaviour only happen in manufacture of food products in both partner, Manufacture of basic metals \& Manufacture of textiles in Japanese market, and manufacture of furniture in Chinese market. From the estimation result, it can be concluded that Indonesian food products exported to China and Japan are quite competitive because the exporter can absorb some of the exchange rate depreciation into their mark up in order to gain more profit. PTM behaviour on basic metals and textiles product only appear on Japanese market, while in Chinese market there's no evidence of PTM (complete exchange rate pass through).

\section{CONCLUSIONS}

In general, the study results show that the degree of absorption of exchange rate changes is imperfect (statistically, the coefficient is between 0 and 1 ) reflecting the behavior of PTM in the exporters of Indonesian industrial products. The summary of this study is that in the case of Indonesia, it was found that differences between export markets are more important than differences across industry.

The rate of inflation and the level of trade openness in export destination countries significantly affect export prices where the inflation rate positively affects export prices, whereas the level of trade openness has a negative effect on export prices. Besides, being influenced by the market conditions of export destinations, export prices are also influenced by the macroeconomic policy conditions in the country. The macroeconomic policy has a negative effect on 
export prices, which indicates that Indonesia's macroeconomic conditions are good enough to push export prices down. Based on the estimation result, there is negative effect of export share on export price. It means that the more Indonesia export, the export price will decrease. It probably due to the very small share and the lack of quality of Indonesian export products that exported to China and Japan so in order to maintain its share in those market, Indonesian exporters have to lowering their export price.

The exchange rate flexibility can facilitate the adjustment of relative prices. However, when the ERPT is low or in other words Indonesian exporters practicing PTM, it can limit the effectiveness of exchange rate policies imposed by Bank Indonesia in influencing export growth. To sum, the PTM behaviour exhibited by exporters would be a challenge for a country that use exchange rate as an instrument to fix the trade balance.

\section{REFERENCES}

[1] Banerjee, A., \& Russel, B. (2001). The relationship between currency The relationship between the markup and inflation in the G7 economies and Australia. Review of Economics and Statistics, 83(2), 377-384. https://doi.org/10.1046/j.0023-5962.2003.00234.x

[2] Banik, N., \& Biswas, B. (2007). Exchange rate pass-through in the U.S. automobile market: A cointegration approach. International Review of Economics and Finance, 16(2), 223-236. https://doi.org/10.1016/j.iref.2005.05.001

[3] Barhoumi, K. (2006). Differences in long run exchange rate passthrough into import prices in developing countries: An empirical investigation. Economic Modelling, 23(6), 926-951. https://doi.org/10.1016/j.econmod.2006.04.006

[4] Bergin, P. R., \& Feenstra, R. C. (2009). Pass-through of exchange rates and competition between floaters and fixers. Journal of Money, Credit and Banking, 41(SUPPL. 1), 35-70. https://doi.org/10.1111/j.15384616.2008.00198.x

[5] Campa, J. M., \& Goldberg, L. S. (2005). Exchange Rate Pass-through into Import Prices. The Review of Economics and Statistics, 87(4), 679690.

[6] Choudhri, E. U., Faruqee, H., \& Hakura, D. S. (2005). Explaining the exchange rate pass-through in different prices. Journal of International Economics, $65(2)$ https://doi.org/10.1016/j.jinteco.2004.02.004

[7] Choudhri, E. U., \& Hakura, D. S. (2006). Exchange rate pass-through to domestic prices: Does the inflationary environment matter? Journal of International Money and Finance, 25(4), 614-639. https://doi.org/10.1016/j.jimonfin.2005.11.009

[8] Engel, C.(1993).Real exchange rates and relative prices: An empirical investigation. Journal of monetary economics, 32(1), 35-50.

[9] Engel,C. \& Rogers,J.H. (1994). How wide is the border? (No.w4829). National Bureau of Economic Research.

[10] Feenstra, R. C. (1989). Symmetric pass-through of tariffs and exchange rates under imperfect competition: An empirical test. Journal of International Economics, 27(1-2), 25-45. https://doi.org/10.1016/00221996(89)90076-7

[11] Feenstra, R. C., Gagnon, J. E., \& Knetter, M. M. (1996). Market share and exchange rate pass-through in world automobile trade. Journal of International Economics, 40, 187-207.

[12] Gagnon, J. E., \& Knetter, M. M. (1995). Markup adjustment and exchange rate fluctuations: evidence from panel data on automobile exports. Journal of International Money and Finance, 14(2), 289-310. https://doi.org/10.1016/0261-5606(94)00004-K

[13] Gaulier, G., Lahr’eche-R`Evil, A., \& Isabelle M’ejean. (2008). Exchange-rate pass-through at the Product Level. Canadian Journal of Economics, 41(2), 425-449.

[14] Giovannini, A. (1988). Exchange rates and traded goods prices. Journal of International Economics, 24(1-2), 45-68. https://doi.org/10.1016/0022-1996(88)90021-9

[15] Goldberg, P. K., \& Knetter, M. M. (1997). Goods prices and exchange rates: What have we learned? Journal of Economic Literature, 35(3), 1243-1272. https://doi.org/10.2307/2729977
[16] Isard, B. P. (1977). How Far Can We Push the "Law of One Price "? The American Economic Review, 67(5), 942-948.

[17] Ito, T., Sasaki, Y. N., \& Sato, K. (2005). Pass-Through of Exchange Rate Changes and Macroeconomic Shocks to Domestic Inflation in East Asian Countries *.

[18] Khundrakpam,J.K. (2007). Economic reforms and exchange rate passthrough to domestic prices in India.

[19] Knetter, M. M. (1989). American Economic Association Price Discrimination by $\mathrm{U}$. S . and German Exporters. The American Economic Review, 79(1), 198-210.

[20] Knetter, M. M. (1993). International Comparisons of Pricing-to-Market Behavior. The American Economic Review, 83(3), 473-486.

[21] Kravis, B. I. B., \& Lipsey, R. E. (1977). American Economic Association Export Prices and the Transmission of Inflation. The American Economic Review, 67(1), 155-163.

[22] Mann, C. L. (1986). Prices, profit margins, and exchange rates. Fed. Res. Bull., 72,366.

[23] Marazzi, M., Sheets, N., Vigfusson, R., Faustj., Gagnon,J.,Marquez, J.\&Rogers, J. (2005). Exchange rate pass-through to US import prices: some new evidence. International Finance Discussion Papers, 833.

[24] Marston, R. C. (1990). Pricing to market in Japanese manufacturing. Journal of International Economics, 29(3-4), 217-236. https://doi.org/10.1016/0022-1996(90)90031-G

[25] Mishkin,F.S.(2008).Exchange rate pass-through and monetary policy (No. w13889). National Bureu of EconomicResearch.

[26] McCarthy, J,. (2007). Pass through of exchange rates and import prices to domestic inflation in some industrialized economies. East Econ J, 33, 511-537

[27] Montiel, P. J. (2003). Tight money in a post-crisis defense of the exchange rate: What have we learned? The World Bank Research Observer, 18(1), 1-23. https://doi.org/10.1093/wbro/lkg001

[28] Otani, A., Shiratsuka, S., \& Shirota, T. (2003). The Decline in the Exchange Rate Pass-Through: Evidence from Japanese Import Prices. Monetary and Economic Studies, (21), 53-81.

[29] Richardson, J. D. (1978). Some empirical evidence on commodity arbitrage and the law of one price. Journal of International Economics, 8(2), 341-351. https://doi.org/10.1016/0022-1996(78)90027-2.

[30] Rogoff. (1996). The Purchasing Power Parity Puzzle. Journal of Economic Literature, 34(2), 647-668.

[31] Shimizu, J., \& Sato, K. (2015). Abenomics, Yen Depreciation, Trade Deficit , and Export Competitiveness. Retrieved from www.rieti.go.jp/jp/publications/dp/15e020.pdf

[32] Taylor, J. B. (2000). Low inflation, pass-through, and the pricing power of firms. European Economic Review, 44(7), 1389-1408. https://doi.org/10.1016/S0014-2921(00)00037-4

[33] Yang, J. (1998). Pricing-to-market in U.S. imports and exports: A time series and cross-sessional study. The Quarterly Review of Economics and Finance, 38(4), 843-861. https://doi.org/10.1016/S10629769(99)80135-5 